\title{
Threat of Zika Virus to the 2016 Rio de Janeiro Olympic and Paralympic Games
}

\author{
Jill E. Weatherhead ${ }^{1} \cdot$ Juliana da Silva $^{1} \cdot$ Kristy O. Murray $^{1}$
}

Published online: 16 July 2016

(C) Springer International Publishing AG 2016

\begin{abstract}
Purpose of Review The emergence of Zika virus (ZIKV) in the Americas has been met with growing concern in the midst of the 2016 Rio de Janeiro Olympic and Paralympic games. This review aims to evaluate the precedence of other arboviruses epidemics in Brazil, historical precedence of large international events in the setting of mosquito-borne disease epidemics, and recent seasonal decrease in notified cases of ZIKV in Rio de Janeiro to determine the safety of proceeding with the 2016 Rio de Janeiro Olympic and Paralympic games as scheduled.

Recent Findings Since the 2013-2014 outbreak in French Polynesia, viral virulence, viral transmission dynamics, and subsequent disease states have evolved. The ZIKV epidemic in the Americas has been associated with viral adaptation to Aedes aegypti and Aedes albopictus leading to increased transmission efficacy and wider geographical distribution. This evolution has fueled concern regarding the upcoming Rio de Janeiro Olympics. However, the 2014 World Cup in Brazil did not result in increased spread of similar vector-borne diseases such as Chikungunya and Dengue viruses, and the 2016 Carnival held in Rio de Janeiro was not linked to further spread of ZIKV around the world.
\end{abstract}

Jill E. Weatherhead

weatherh@bcm.edu

Juliana da Silva

juliana.dasilva@bcm.edu

Kristy O. Murray

kmurray@bcm.edu

1 National School of Tropical Medicine, Baylor College of Medicine, Houston, TX, USA
Summary While many uncertainties remain regarding pathogenesis and transmission of ZIKV, minimal evidence exists to suggest that holding the Olympic and Paralympic games in Rio de Janeiro in 2016 will contribute to further spread of ZIKV globally. However, the CDC and WHO still recommend appropriate personal protective precautions for all international travelers to the 2016 Olympic Games in Rio de Janeiro to minimize risks.

Keywords Olympics · Zika virus · Rio de Janeiro · Brazil · Aedes mosquito

\section{Introduction}

ZIKV (ZIKV), an emerging infectious disease spreading rapidly throughout the Americas, is a single-stranded RNA flavivirus transmitted by the bite of the Aedes spp. mosquito [1,2]. The virus was first isolated from the serum of a rhesus macaque in 1947 in the Zika Forest of Uganda and first isolated from a human in 1952 [3,4]. From 1952 until 2007, sporadic infections were geographically restricted to areas of Africa (African lineage strain) and Asia (Asia lineage strain) [3,5].

The first major ZIKV outbreak occurred in 2007 on Yap Island, Federate states of Micronesia, during which $73 \%$ of the population was presumed to be infected. Despite a large proportion of individuals infected, an epidemiologic investigation estimated that $80 \%$ of all ZIKV infections were asymptomatic. Those that displayed symptoms tended to have a mild febrile illness, similar to related arboviruses, with associated exanthematous rash, arthralgia, headache, and conjunctivitis lasting approximately 1 week [4-6]. However, from 20132014, a second outbreak occurred in French Polynesia with over 32,000 cases of documented ZIKV-like illness. Interestingly, during the French Polynesia ZIKV outbreak, an 
increasing number of disease complications not previously reported were identified including fetal intrauterine growth restriction, fetal demise, fetal and infant microcephaly, and autoimmune disorders such as Guillain Barré Syndrome $[4,5]$.

Further spread of ZIKV occurred from 2014 to early 2015 when the first autochthonous case in the Americas was detected in Brazil. The introduction of the virus onto the South American continent was initially linked to two large sporting events that occurred in Brazil, FIFA World Cup, and the Va'a World Spring Championship canoe race [3]. However, more recent phylogenic modeling suggests the virus was likely introduced into the region between May and December of 2013 prior to either of these events [5,7]. Since the first Brazilian autochthonous case in early 2015, there has been rapid spread of ZIKV throughout Latin America and the Caribbean. Documented symptoms associated with ZIKV during the current Americas outbreak have supported the more severe disease outcomes highlighted during the French Polynesia outbreak. As of May 2016, 58 countries and territories in the Americans have recorded local transmission of ZIKV. In the US, 503 travel-associated cases have been reported to the CDC [8]. To date, no autochthonous cases have been reported in the US outside of Puerto Rico [8].

\section{Evolution of ZIKV Transmission Dynamics}

It is evident that since the onset of the French Polynesia and Americas' outbreaks, viral virulence and transmission dynamics have evolved. ZIKV has a known single open reading frame that is cleaved into three structural proteins, capsid (C), membrane precursor (prM), and envelope (E) as well as 7 non-structural proteins $[1,2,9,10]$. The E protein is the major virion surface protein involved in the transmission cycle, responsible for receptor binding and membrane fusion $[1,11]$. During the previous French Polynesia and the current America outbreak, which has involved rapid spread of the virus as well as a shift from a predominant sylvatic to an urban transmission cycle, it is postulated that ZIKV may have experienced amino acid substitutions in the E protein and genetic recombination with associated structural changes [9,12]. Loss of the N154 glycosylation site on the E protein is associated with viral adaption to Aedes spp. such as Aedes aegypti and Aedes albopictus, species associated with increased human transmission efficacy and wider geographical distribution including urban centers. While the impact of these genomic modifications is unknown, they may be linked to the enhanced viral pathogenicity and transmissibility in the current outbreak $[1,3,12]$. Phylogenetic analysis from strains originating from the Americas has resulted in identification of a new American clade within the Asian lineage, closely related to the strain identified during the French Polynesia outbreak [12,13].
ZIKV transmission dynamics are largely unknown. Clinical and laboratory experiences with closely related flaviviruses in combination with clinical cases, animal models, and cell culture techniques have provided estimates on viral infectivity. Transmission potential modeling of ZIKV in Colombia has estimated the reproduction number $\mathrm{R}_{0}$, number of new cases generated by a single human case via a mosquito vector, range from 3.0 to 6.6 , which is similar to other mosquito-borne arboviruses. This estimate matches the $\mathrm{R}_{0}$ described in both the Yap Island and French Polynesia outbreak [14].

After vector-induced inoculation of the virus into the host, the virus is believed to infect epidermal keratinocytes, skin fibroblasts, and dendritic cells. The virus subsequently maximizes viral replication by inducing autophagy in host cells followed by rapid spread to regional lymph nodes and global dissemination via the lymphatic and circulatory systems $[2,11]$. Incubation time periods range from 3 to 14 days while viremia may be detected as early as the first day of symptom onset until as late as the 11th day after symptom onset [2,15]. Despite the known transmission via an arthropod vector, the recent outbreak of ZIKV in the Americas has highlighted other potential sources of infection including vertical, blood transfusion, and sexual transmission [2,15].

Perinatal or vertical transmission from mother to child of ZIKV has been reported and is now widely accepted as a cause of severe congenital disease, including microcephaly. Intrauterine transmission is of particular concern in Brazil where infants born to infected mothers have had detectable virus by real-time polymerase chain reaction (RT-PCR) in tissue with corresponding clinical disease. ZIKV was detected in fetal brain tissue on autopsy of an infected fetus with microcephaly and cerebral calcifications. The mother had been infected with ZIKV during the first trimester of pregnancy in Northeastern Brazil [16]. Replicating Zika viral complexes have also been detected in amniotic fluid of two fetuses with microcephaly [17]. As a result of vertical transmission, fetuses and infants of women who test positive for ZIKV may have grave outcomes including fetal death, growth restriction with evidence of placental insufficiency, hydrops fetalis, and abnormal amniotic fluid volume, central nervous system abnormalities including microcephaly, ventricular calcifications, and hydranencephaly [18,19]. The transmission dynamics during pregnancy and the perinatal period are unknown. Some reports suggest serious adverse outcomes to the fetus, mimicking other congenitally acquired viruses such as cytomegalovirus (CMV), occur with maternal infection during the first trimester [15]. Studies have documented that fetuses exposed to ZIKV in utero are at risk of developing severe brain anomalies including cortical hypogyration and white matter hypomyelination indicating restriction in brain development. In the absence of overt brain tissue destruction, these brain anomalies indicate likely vertical transmission during early 
pregnancy [20]. Furthermore, during the 2013 French Polynesia outbreak, a set of mothers and their newborns tested positive for ZIKV by RT-PCR from serum during the immediate post-partum time period. Interestingly, breast milk from the infected mothers also tested positive for ZIKV by RTPCR; however, no replicative viral particles were detected [21]. It remains plausible that ZIKV could be transmitted perinatally not only via intrauterine transmission but also during delivery, breastfeeding, or close contact after birth with bodily fluids such as saliva [11].

Similar to other flaviviruses transmitted via blood transfusion, ZIKV poses a threat to transfusion medicine. Many viremic individuals may have asymptomatic infection leading to potential donor blood contamination if no screening tests are available [9]. In 2013, during the French Polynesia outbreak, $3 \%$ of all blood donors were positive for ZIKV and only $26.2 \%$ of these patients recalled a "Zika fever-like syndrome" during the weeks prior to blood donation [22]. While blood product-related transmission remains a concern, minimal data is currently available detailing the prevalence of ZIKV in asymptomatic donors during the current outbreak [9].

Sexual transmission of ZIKV from men to their partners has been documented since 2008 with high levels of replicating virus detected in semen [23]. During the current ZIKV outbreak in the Americas, a total of 10 confirmed cases of sexual transmission in the US have been documented $[8,23,24]$. Transmission dynamics of ZIKV in semen are currently unknown; however, reports of replicating virus have been isolated from semen up to 62 days after the onset of illness and after viremia has cleared [24,25]. Currently, it is unknown if asymptomatic men or women can transmit ZIKV to their partners or if infection can occur secondary to oral sexual intercourse $[15,24,26]$.

Other non-vector modes of ZIKV transmission currently under investigation, but with minimal data, include transmission via mucocutaneous exposure to virus, animals bite, urine, hemodialysis, organ transplant, and respiratory droplet [11]. Surveillance studies have been done to monitor presence and persistence of virus in additional bodily fluids including saliva, with evidence of detection up to 29 days post-infection, and urine, with evidence of virus detection 4 days after onset of symptoms and persisting beyond 14 days after onset of symptoms $[27,28]$. Despite the detection of virus in these alternative sources, the risk of transmission remains questionable.

\section{Rio de Janeiro, Zika, and the 2016 Olympic Games}

The evolution of ZIKV virulence and transmission potential has raised concerns regarding the practicality and global safety of proceeding with the 2016 Rio de Janeiro Olympic and Paralympic games scheduled from August fifth through September 18th, 2016. Rio de Janeiro is a coastal city in the southeast of Brazil. It is the second most populous city in the country and an important economic and cultural hub, with second highest GDP in Brazil. It is also the capital of homonymous state, Rio de Janeiro. The city of Rio de Janeiro, where the games will take place has an estimated population of 6.4 million habitants [29]. Introduction of ZIKV into the city has been estimated to be as early as January 2015, and the peak of the outbreak was documented in May-June 2015 during the dry season with an atypically high accumulation of precipitation [30]. To date, the Ministry of Heath of Brazil estimates 91,387 probable cases of ZIKV fever in the country (incidence 44.7 cases $/ 100,000$ population), with 25,930 suspected cases documented in the state of Rio de Janeiro, leading to an incidence rate of 156.7 per 100,000 inhabitants. Since November 2015, the state of Rio de Janeiro has had a total of 445 reported cases of microcephaly with 55 confirmed cases related to ZIKV infection and another 282 remaining under investigation, according to data from Brazilian Ministry of Health and Rio de Janeiro State Health Department [31]. A total of 9472 suspected cases of ZIKV infections during pregnancy (as defined by pregnant women with an exanthematic rash) were identified in the state of Rio de Janeiro from November 2015 to May 2016. Of those women, $34.96 \%(n=1154)$ had confirmed ZIKV infection [31]. Furthermore, health authorities from the state of Rio de Janeiro have identified 193 suspected and 9 confirmed cases of ZIKV-associated Guillain Barré syndrome (as defined as neurological syndrome post exanthematic rash) [31].

In the setting of on-going transmission of ZIKV in Brazil, there remains a potential for sustained transmission and further global spread secondary to the international influx of visitors into Brazil, specifically Rio de Janeiro, anticipated in 2016. Brazilian officials are estimating over 1 million international visitors will travel to Brazil in the year of 2016, with between 300,000 and 500,000 foreign visitors planning to attend the Olympic and Paralympic games in Rio de Janeiro [32]. The city of Rio de Janeiro will host athletes and tourists from approximately 204 countries during the course of the games [33]. With the dense urban population and the thousands of previously uninfected tourists, there is potential to facilitate spread of ZIKV to other areas of the world secondary to infected travelers.

\section{Rationale for Risk Assessment of Zika Pandemic Due to the Olympics Games in Rio de Janeiro}

While many uncertainties remain regarding pathogenesis and transmission of ZIKV, minimal evidence exists to support the fear that holding the Olympic and Paralympic games in Rio de Janeiro in 2016 will fuel the further spread of ZIKV globally. Spread of arboviruses is based not only on human travel but also on the environment and cultural milieu including local vector control, climate and season, and human-mosquito 
contact patterns [5]. It is reasonable to state that, if appropriate personal protective precautions are taken, international attendance to Olympic Games should not result in a heightened spread of ZIKV. In support of this statement, we present below an analysis of other arboviruses epidemics in Brazil, historical precedence of large international events in the setting of mosquito-borne disease epidemics, and recent seasonal decrease in notified cases of ZIKV in Rio de Janeiro.

\section{Dengue Epidemics in Brazil}

Dengue is an arbovirus that shares many similarities with ZIKV. Like ZIKV, Dengue virus is transmitted through the bite of the Aedes mosquito. However, dengue epidemics have consistently affected the Rio de Janeiro area and Brazil at large for decades. In 2014, over 656,800 US citizens visited Brazil, accounting for $10 \%$ of international visitors into the country [34], in that same year, Brazil had 587,000 cases of dengue reported and yet, apart from few sporadic cases in continental US, dengue remained mostly confined to US territories in Puerto Rico, the US Virgin Islands, Samoa, and Guam [35].

\section{FIFA World Cup 2015 and Carnival in Rio de Janeiro 2016}

Historical precedence from a similar vector-borne disease outbreak in the Americas during the 2014 FIFA World cup does not support the concerns that holding the Olympics and Paralympics in Rio de Janeiro will facilitate additional spread of ZIKV specifically to the US. The rapid spread of Chickungunya (CHIKV), an alphavirus transmitted through the bite of the Aedes mosquito, throughout the Americas was occurring during the time of the 2014 FIFA World Cup held in Brazil, June-July 2014 [36]. Thirty-two international teams participated in the World Cup and over 3,429,873 national and international fans (36\% determined to be international) were in attendance in Brazil [37]. Furthermore, over 937,330 people attended FIFA Fan Fest (an enclosed area equipped with televisions and live entertainment) in Rio de Janeiro alone [37]. The large influx of international travelers into Brazil during the 2014 CHIKV outbreak had the potential of influencing worldwide spread of CHIKV disease particularly in the US. However, according to ArboNet, in 2014 a total of 2811 chikungunya virus were reported from the US with 12 locally acquired cases in Florida but decreased in 2015 to a total of 679 cases and no locally transmitted cases in the US [38].

Another historical example is related to the recent Carnival festivities in Rio de Janeiro, celebrated in early February, at the height of rainy season. It is estimated that 1 million tourists were in attendance [39], with $26 \%$ of those being American citizens [40] attending events in Rio de Janeiro alone. Additionally, several thousand visitors attended other popular Carnival destinations in the Northeast of the country, a region also heavily affected area by the ZIKV epidemic. Despite this risk, an increase in the number of ZIKV cases travelers returning from Carnival during the same time period has not been observed.

\section{Recent Epidemiologic Trends of Zika in Rio de Janeiro}

Despite this potential, public health surveillance being conducted by the Ministry of Health of Brazil has demonstrated a current downward trend of reported ZIKV-related illnesses including microcephaly and neurologic sequelae [41]. This decreasing trend in Brazil and specifically Rio de Janeiro may be related to the seasonal transition from the rainy season, typically lasting from December to March, to the more mild winter season, which peaks from July to August, leading to fewer active mosquitoes [42]. These trends are consistent with the findings of other arboviruses such as Dengue which typically have seasonal low transmission during the winter months in Brazil [42]. If following similar trends, it would be predicted that ZIKV transmission should be reduced significantly during the timeframe of the Olympic and Paralympic games.

\section{Recommendations Regarding the Olympics and Paralympic Games}

While at the current time there is insufficient evidence to support canceling or moving the Olympic and Paralympic games from Brazil, precautions for travelers to Brazil remain. Currently, the World Health Organization and the US Centers for Disease Control and Prevention recommend pregnant women to not travel to areas with on-going transmission which includes the region where the Olympics and Paralympic games will take place $[8,42]$. Furthermore, sexual partners of pregnant women who travel to the Olympics should abstain from intercourse throughout the rest of the pregnancy or use condoms to prevent virus transmission [42]. Men with ZIKV symptoms should wait at least 6 months before attempting conception with partners [8]. Those individuals who attend the Olympics and Paralympics but are not pregnant or not attempting conception should still use safe sex practices or abstain from sex during their stay in Brazil and for at least 8 weeks after their return. If they develop ZIKV-like symptoms, presumed ZIKVinfected individuals should use safe sex practices for 6 months after return $[8,42]$. People who travel to endemic areas throughout the Americas should continue to take extra precautions to avoid mosquito bites through using and reapplying insect repellent, wearing light-colored clothing that covers the entire body, choosing accommodations with air conditioning in order to keep windows closed, and avoiding areas with poor sanitation $[8,42]$.

Finally, it is important to highlight that dengue, rather than Zika, should be faced as the biggest health threat to visitors planning to attend Olympic games, whereas Zika 
has 91,000 probable cases and three confirmed deaths, [43] dengue has so far resulted in over 1 million probable cases with 190 deaths [43].

\section{Conclusions}

The emergence of ZIKV in the Americas has been met with growing concern in the midst of the upcoming 2016 Rio de Janeiro Olympic and Paralympic games. While the risk of further transmission and global spread to areas harboring the Aedes mosquito vector is plausible, based on previous arboviral outbreak dynamics and the seasonality of disease transmission, the Rio Olympic and Paralympic games should proceed as planned. Both the CDC and WHO have made official statements against cancelation of Olympic Games. CDC officials pointed that travel to Olympic games represent less than $0.25 \%$ of all travel to Zika affected countries [44] and therefore attending Olympics games in Rio de Janeiro would not significantly impact in further Zika spread. Potential travelers to the Rio Olympics and Paralympics should be educated on the risk of ZIKV prior to their trip and should practice precautionary measures including travel restrictions for certain populations, safe sex practices among males and females as well as extreme mosquito avoidance. After completion of the games, it will be imperative for countries to monitor for signs of ZIKV transmission and ZIKV disease states through epidemiologic surveillance and physician reporting of cases.

Acknowledgments Thanks to Dr. Coreen Beaumier for reviewing and providing feedback on the content and quality of this article.

\section{Compliance with Ethical Standards}

Conflict of Interest The authors have no conflict of interests related to this manuscript.

Human and Animal Rights and Informed Consent This article does not contain any studies with human or animal subjects performed by any of the authors.

\section{References}

Papers of particular interest, published recently, have been highlighted as:

- Of importance

1. Faye O, Freire CCM, Iamarino A, Faye O, de Oliveira JVC, Diallo $\mathrm{M}$, et al. Molecular evolution of Zika virus during its emergence in the 20(th) century. PLoS Negl Trop Dis [Internet]. 2014;8(1): e2636. Available from: http://www.ncbi.nlm.nih. gov/pubmed/24421913.
2. Hayes EB. Zika virus outside Africa. Emerg Infect Dis [Internet]. 2009;15(9):1347-50. Available from: http://www.ncbi.nlm.nih. gov/pubmed/19788800.

3. Zhu Z, Chan JF-W, Tee K-M, Choi GK-Y, Lau SK-P, Woo PC-Y, et al. Comparative genomic analysis of pre-epidemic and epidemic Zika virus strains for virological factors potentially associated with the rapidly expanding epidemic. Emerg Microbes Infect [Internet]. 2016;5:e22. Available from: http://www.ncbi.nlm.nih. gov/pubmed/26980239.

4. Paixão ES, Barreto F, da Glória Teixeira M, da Conceição N, Costa M, Rodrigues LC. History, epidemiology, and clinical manifestations of Zika: a systematic review. Am J Public Health [Internet]. 2016;106(4):606-12. Available from: http://www.ncbi.nlm.nih. gov/pubmed/26959260. ZIKV in the Americas is linked to increased neurologic disorders including fetal microcephaly. Improvement in diagnostics, treatment and vector control are needed for control of further spread of the virus globally.

5. Messina JP, Kraemer MU, Brady OJ, Pigott DM, Shearer FM, Weiss DJ, et al. Mapping global environmental suitability for Zika virus. Elife [Internet]. 2016 [cited 2016 Jun 2];5. Available from: http://www.ncbi.nlm.nih.gov/pubmed/27090089.

6. Duffy MR, Chen T-H, Hancock WT, Powers AM, Kool JL, Lanciotti RS, et al. Zika virus outbreak on Yap Island, Federated States of Micronesia. N Engl J Med [Internet]. 2009;360(24):253643. Available from: http://www.ncbi.nlm.nih. gov/pubmed/19516034.

7. Faria NR, Azevedo R do S da S, Kraemer MUG, Souza R, Cunha MS, Hill SC, et al. Zika virus in the Americas: Early epidemiological and genetic findings. Science [Internet]. 2016 Apr 15 [cited 2016 Jun 2];352(6283):345-9. Available from: http://www.ncbi. nlm.nih.gov/pubmed/27013429. The introduction of ZIKV into the Americas has been molecularly mapped to have occurred in 2013 prior to two large international sporting events that occurred in Brazil.

8. Center for Disease Control and Prevention. Zika Virus [Internet]. 2016 [cited 2016 May 1]. Available from: http://www.cdc. gov/zika/.

9. Marano G, Pupella S, Vaglio S, Liumbruno GM, Grazzini G. Zika virus and the never-ending story of emerging pathogens and transfusion medicine. Blood Transfus [Internet]. 2016;14(2):95-100. Available from: http://www.ncbi.nlm.nih.gov/pubmed/26674815.

10. Cunha MS, Esposito DLA, Rocco IM, Maeda AY, Vasami FGS, Nogueira JS, et al. First complete genome sequence of Zika Virus (Flaviviridae, Flavivirus) from an autochthonous transmission in Brazil. Genome Announc [Internet]. 2016;4:2. Available from: http://www.ncbi.nlm.nih.gov/pubmed/26941134.

11. Chan JFW, Choi GKY, Yip CCY, Cheng VCC, Yuen K-Y. Zika fever and congenital Zika syndrome: An unexpected emerging arboviral disease. J Infect [Internet]. 2016 Mar 3 [cited 2016 Apr 5]; Available from: http://www.ncbi.nlm.nih. gov/pubmed/26940504.

12. Han J-F, Jiang T, Ye Q, Li X-F, Liu Z-Y, Qin C-F. Homologous recombination of Zika viruses in the Americas. J Infect [Internet]. 2016 Apr 19 [cited 2016 Jun 2]; Available from: http://www.ncbi. nlm.nih.gov/pubmed/27105655.

13. Lanciotti RS, Lambert AJ, Holodniy M, Saavedra S, Signor LDCC. Phylogeny of Zika virus in western hemisphere, 2015. Emerg Infect Dis [Internet]. 2016;22(5):933-5. Available from: http://www.ncbi. nlm.nih.gov/pubmed/27088323.

14. Nishiura H, Mizumoto K, Villamil-Gómez WE, RodríguezMorales AJ. Preliminary estimation of the basic reproduction number of Zika virus infection during Colombia epidemic, 2015-2016. Travel Med Infect Dis [Internet]. 2016 Apr 7 [cited 2016 Jun 2]; Available from: http://www.ncbi.nlm.nih.gov/pubmed/27060613.

15. Petersen EE, Polen KND, Meaney-Delman D, Ellington SR, Oduyebo T, Cohn A, et al. Update: interim guidance for health care 
providers caring for women of reproductive age with possible Zika virus exposure-United States, 2016. MMWR Morb Mortal Wkly Rep [Internet]. 2016;65(12):315-22. Available from: http://www. ncbi.nlm.nih.gov/pubmed/27031943.

16. Mlakar J, Korva M, Tul N, Popović M, Poljšak-Prijatelj M, Mraz J, et al. Zika virus associated with microcephaly. N Engl J Med [Internet]. 2016;374(10):951-8. Available from: http://www.ncbi. nlm.nih.gov/pubmed/26862926.

17. Calvet G, Aguiar RS, Melo ASO, Sampaio SA, de Filippis I, Fabri $\mathrm{A}$, et al. Detection and sequencing of Zika virus from amniotic fluid of fetuses with microcephaly in Brazil: a case study. Lancet Infect Dis [Internet]. 2016 Feb 17 [cited 2016 Jun 2]; Available from: http://www.ncbi.nlm.nih.gov/pubmed/26897108.

18. Brasil P, Pereira JP, Raja Gabaglia C, Damasceno L, Wakimoto M, Ribeiro Nogueira RM, et al. Zika Virus Infection in Pregnant Women in Rio de Janeiro - Preliminary Report. N Engl J Med [Internet]. 2016 Mar 4 [cited 2016 Jun 2]; Available from: http:/www.ncbi.nlm.nih.gov/pubmed/26943629.

19. Sarno M, Sacramento GA, Khouri R, Do Rosário MS, Costa F, Archanjo G, et al. Zika virus infection and stillbirths: a case of hydrops fetalis, hydranencephaly and fetal demise. PLoS Neg1 Trop Dis [Internet]. 2016;10(2):e0004517. Available from: http://www.ncbi.nlm.nih.gov/pubmed/26914330.

20. Hazin AN, Poretti A, Turchi Martelli CM, Huisman TA. Microcephaly Epidemic Research Group, Di Cavalcanti Souza Cruz D, et al. Computed tomographic findings in microcephaly associated with Zika virus. N Engl J Med [Internet]. 2016;374(22):2193-5. Available from: http://www.ncbi.nlm.nih. gov/pubmed/27050112.

21. Besnard M, Lastere S, Teissier A, Cao-Lormeau V, Musso D. Evidence of perinatal transmission of Zika virus, French Polynesia, December 2013 and February 2014. Euro Surveill Bull Eur sur les Mal Transm=Eur Commun Dis Bull [Internet]. 2014;19:13. Available from: http://www.ncbi.nlm.nih. gov/pubmed/24721538.

22. Musso D, Nhan T, Robin E, Roche C, Bierlaire D, Zisou K, et al. Potential for Zika virus transmission through blood transfusion demonstrated during an outbreak in French Polynesia, November 2013 to February 2014. Euro Surveill Bull Eur sur les Mal Transm =Eur Commun Dis Bull [Internet]. 2014;19:14. Available from: http://www.ncbi.nlm.nih.gov/pubmed/24739982.

23. Musso D, Roche C, Robin E, Nhan T, Teissier A, Cao-Lormeau VM. Potential sexual transmission of Zika virus. Emerg Infect Dis [Internet]. 2015;21(2):359-61. Available from: http://www.ncbi. nlm.nih.gov/pubmed/25625872.

24. Oster AM, Russell K, Stryker JE, Friedman A, Kachur RE, Petersen $\mathrm{EE}$, et al. Update: interim guidance for prevention of sexual transmission of Zika virus - United States, 2016. MMWR Morb Mortal Wkly Rep [Internet]. 2016;65(12):323-5. Available from: http://www.ncbi.nlm.nih.gov/pubmed/27032078.

25. Atkinson B, Hearn P, Afrough B, Lumley S, Carter D, Aarons EJ, et al. Detection of Zika virus in Semen. Emerg Infect Dis [Internet]. 2016;22(5):940. Available from: http://www.ncbi.nlm.nih. gov/pubmed/27088817.

26. D’Ortenzio E, Matheron S, Yazdanpanah Y, de Lamballerie X, Hubert B, Piorkowski G, et al. Evidence of sexual transmission of Zika virus. N Engl J Med [Internet]. 2016;374(22):2195-8. Available from: http://www.ncbi.nlm.nih.gov/pubmed/27074370.

27. Rozé B, Najioullah F, Fergé J-L, Apetse K, Brouste Y, Cesaire R, et al. Zika virus detection in urine from patients with Guillain-Barré syndrome on Martinique, January 2016. Euro Surveill Bull Eur sur les Mal Transm =Eur Commun Dis Bull [Internet]. 2016;21:9. Available from: http://www.ncbi.nlm.nih.gov/pubmed/26967758.

28. Barzon L, Pacenti M, Berto A, Sinigaglia A, Franchin E, Lavezzo $\mathrm{E}$, et al. Isolation of infectious Zika virus from saliva and prolonged viral RNA shedding in a traveller returning from the Dominican Republic to Italy, January 2016. Euro Surveill Bull Eur sur les Mal Transm=Eur Commun Dis Bull [Internet]. 2016;21:10. Available from: http://www.ncbi.nlm.nih.gov/pubmed/26987769.

29. IBGE. Instituto Brasileiro de Geografia e Estatistica [Internet]. 2016 [cited 2016 May 19]. Available from: cidades.ibge.gov.br/

30. Brasil P, Calvet GA, Siqueira AM, Wakimoto M, de Sequeira PC, Nobre A, et al. Zika virus outbreak in Rio de Janeiro, Brazil: clinical characterization, epidemiological and virological aspects. PLoS Negl Trop Dis [Internet]. 2016;10(4):e0004636. Available from: http://www.ncbi.nlm.nih.gov/pubmed/27070912. ZIKV was first detected in Rio de Janeiro, Brazil as early as January 2015 and peaked by May/June 2015. The emergence of ZIKV in Rio de Janiero highlighted the need for increased epidemiologic surveillance within the region.

31. Rio de Janeiro State Health Department. Epidemiological report on Zika, Dengue and Chikungunya [Internet]. 2016 [cited 2016 May 19]. Available from: http://www.riocomsaude.rj.gov. $\mathrm{br} / \mathrm{site} /$ conteudo/.

32. Rodrigo Viga Gaier. Brasil espera receber 1 milhao de turistas estrangeiros em 2016 com Olimpiada, diz ministro [Internet]. 2016 [cited 2016 May 19]. Available from: http://www.estadao. com.br/noticias/geral,brasil-espera-receber-1-milhao-de-turistasestrangeiros-em-2016-com-olimpiada-diz-ministro, 1562393.

33. George Utley. IOC Predicts 480,000 Tourists in Rio for 2016 Olympics [Internet]. The Rio Times. 2016 [cited 2016 May 19]. Available from: http://riotimesonline.com/brazil-news/riobusiness/ioc-predicts-480000-tourists-in-rio-2016/\#.

34. blog.planalto.gov.br.

35. Centers for Disease Control and Prevention. Dengue Epidemiology [Internet]. 2016 [cited 2016 May 19]. Available from: http://www. cdc.gov/Dengue/Epidemiology/index.html.

36. Cauchemez S, Ledrans M, Poletto C, Quenel P, de Valk H, Colizza $\mathrm{V}$, et al. Local and regional spread of chikungunya fever in the Americas. Euro Surveill Bull Eur sur les Mal Transm=Eur Commun Dis Bull [Internet]. 2014;19(28):20854. Available from: http://www.ncbi.nlm.nih.gov/pubmed/25060573.

37. 65th FIFA Congress. FIFA Activity Report 2014 [Internet]. 2015. [cited 2016 May 19]. Available from: http://resources.fifa. $\mathrm{com} / \mathrm{mm} /$ document/affederation/administration/02/60/91/68 /fifaactivityreport2014-en_neutral.pdf.

38. Centers for Disease Control and Prevention. Chikungunya virus in the United States [Internet]. 2016 [cited 2016 May 19]. Available from: https://www.cdc.gov/chikungunya/geo/united-states.html.

39. Empresa de Turismo do Municipio do Rio de Janeiro. Em 2016, um carnaval de numeros olimpicos para o turismo carioca [Internet]. Prefeitura do Rio de Janeiro. 2016 [cited 2016 May 19]. Available from: http://www.rio.rj.gov.br/web/riotur/exibeconteudo? id $=5914149$.

40. Da Redacao. Quem e o turista internacional que visitou o Rio no Carnaval 2016? [Internet]. Portal events. 2016 [cited 2016 May 19]. Available from: http://www.revistaeventos.com.br/EventosSociais/Quem-e-o-turista-internacional-que-visitou-o-Rio-noCarnaval-2016/38369.

41. SECRETARIA DE ESTADO DE SAÚDE DO RIO DE JANEIRO. INFORMATIVO CIEVS 021/2016 [Internet]. 2016. [cited 2016 May 19]. Available from: http://www.riocontradengue.com. br/Publico/MostrarArquivo.aspx?C=cfAmp2Oia\%2FM\%3D.

42. WHO. Zika virus. WHO. World Health Organization. 2016.

43. Boletim Epidemiológico Secretaria de Vigilância em Saúde -Ministério da Saúde.

44. Frieden T. Transcript: CDC Director Addresses National Press Club [Internet]. Centers for Disease Control and Prevention. [cited 2016 May 26]. Available from: http://www.cdc.gov/media/releases/2016 /t0526-npc.html. 